De Labra-Hernández, M. Á., and K. Renton. 2017. Factors influencing density of the Northern Mealy Amazon in three forest types of a modified rainforest landscape in Mesoamerica. Avian Conservation and Ecology 12(1):5. https://doi.org/10.5751/ACE-00957-120105

Copyright (C) 2017 by the author(s). Published here under license by the Resilience Alliance.

Research Paper

\title{
Factors influencing density of the Northern Mealy Amazon in three forest types of a modified rainforest landscape in Mesoamerica
}

\author{
Miguel Ángel De Labra-Hernández ${ }^{1}$ and Katherine Renton ${ }^{2}$ \\ ${ }^{1}$ Posgrado en Ciencias Biológicas, Instituto de Biología, Universidad Nacional Autónoma de México, Mexico City, México, ${ }^{2}$ Estación \\ de Biología Chamela, Instituto de Biología, Universidad Nacional Autónoma de México, Jalisco, México
}

\begin{abstract}
The high rate of conversion of tropical moist forest to secondary forest makes it imperative to evaluate forest metric relationships of species dependent on primary, old-growth forest. The threatened Northern Mealy Amazon (Amazona guatemalae) is the largest mainland parrot, and occurs in tropical moist forests of Mesoamerica that are increasingly being converted to secondary forest. However, the consequences of forest conversion for this recently taxonomically separated parrot species are poorly understood. We measured forest metrics of primary evergreen, riparian, and secondary tropical moist forest in Los Chimalapas, Mexico. We also used point counts to estimate density of Northern Mealy Amazons in each forest type during the nonbreeding (Sept 2013) and breeding (March 2014) seasons. We then examined how parrot density was influenced by forest structure and composition, and how parrots used forest types within tropical moist forest. Overall, parrot density was high in the breeding season, with few parrots present during the nonbreeding season. During the breeding season, primary forest had significantly greater density of 18.9 parrots $/ \mathrm{km}^{2}$ in evergreen forest and 35.9 parrots $/ \mathrm{km}^{2}$ in riparian forest, compared with only 3.4 parrots $/ \mathrm{km}^{2}$ in secondary forest. Secondary forest had significantly lower tree species richness, density, diameter, total height, and major branch ramification height, as well as distinct tree species composition compared with both types of primary forest. The number of parrots recorded at point counts was related to density of large, tall trees, characteristic of primary forest, and parrots used riparian forest more than expected by availability. Hence, the increased conversion of tropical moist forest to secondary forest is likely to lead to reduced densities of forest-dependent species such as the Northern Mealy Amazon. Furthermore, the species' requirement for primary tropical moist forest highlights the need to reevaluate conservation status of the Northern Mealy Amazon, and implement strategies to reduce forest conversion.
\end{abstract}

\section{Facteurs influant sur la densité de l'Amazone guatémaltèque dans trois types forestiers d'un paysage altéré en forêt pluviale de Méso-Amérique}

RÉSUMÉ. Le taux élevé de conversion des forêts tropicales humides en forêts secondaires rend impératif l'évaluation des relations entre les paramètres forestiers et les espèces dépendantes des vieilles forêts primaires. L'Amazone guatémaltèque (Amazona guatemalae), espèce menacée, est le plus gros perroquet continental; cette amazone s'observe dans les forêts tropicales humides mésoaméricaines, qui subissent de plus en plus de conversion en forêts secondaires. Cependant, les conséquences de la conversion forestière sur cette espèce, qu'on vient de séparer taxinomiquement, sont mal connues. Nous avons mesuré les paramètres dans des peuplements primaires de forêt tropicale humide d'arbres à feuillage persistant et riparienne, ainsi que dans des peuplements secondaires de forêt tropicale humide dans la région de Los Chimalapas, au Mexique. Nous avons aussi fait des dénombrements par point d'écoute pour estimer la densité d'Amazones guatémaltèques dans chaque type forestier, hors saison de nidification (septembre 2013) et en saison de nidification (mars 2014). Nous avons ensuite examiné de quelle façon la structure et la composition forestière influençaient la densité de ce perroquet, et comment les perroquets utilisaient les divers types forestiers de la forêt tropicale humide. Globalement, la densité de perroquets était élevée durant la saison de nidification et peu de perroquets étaient présents en dehors de cette saison. Durant la nidification, la forêt primaire accueillait des densités significativement plus élevées, tant dans les peuplements d'arbres à feuillage persistant $\left(18,9\right.$ perroquets $\left./ \mathrm{km}^{2}\right)$ que les peuplements ripariens $\left(35,9\right.$ perroquets $\left./ \mathrm{km}^{2}\right)$, comparativement à 3,4 perroquets $/ \mathrm{km}^{2}$ seulement dans les peuplements secondaires. En comparaison aux deux types de peuplements primaires, les paramètres suivants des peuplements secondaires étaient significativement plus faibles : la richesse spécifique d'arbres, la densité d'arbres, le diamètre, la hauteur totale, la hauteur de ramification des branches principales et la composition en certaines essences d'arbres. Le nombre de perroquets notés aux points d'écoute était relié à la densité de grands et gros arbres, caractéristiques des peuplements primaires, et les perroquets ont utilisé les peuplements ripariens au-delà de leur disponibilité. En somme, la conversion accélérée de la forêt tropicale humide en forêt secondaire va vraisemblablement mener à la réduction de la densité des espèces dépendantes des forêts telles que l'Amazone guatémaltèque. De plus, les besoins en matière de forêt tropicale humide primaire de l'Amazone guatémaltèque soulignent la nécessité de réévaluer son statut de conservation et d'élaborer des stratégies afin de diminuer la conversion forestière.

Key Words: Amazona guatemalae; conservation ecology; forest conversion; forest structure and composition; General Additive Models; habitat use and availability; Psittacidae; tropical moist forest

Address of Correspondent: Katherine Renton, Estación de Biología Chamela (IB-UNAM), Aptdo. Postal 21, San Patricio Melaque , Jalisco, CP 48980, México,krenton@ib.unam.mx 


\section{INTRODUCTION}

Land transformation due to anthropogenic activities affects almost half the Earth's surface, and is the primary driving force in the loss of biodiversity (Vitousek et al. 1997). Tropical moist broadleaf forest has one of the highest rates of deforestation, and is increasingly being reduced to forest remnants within a mosaic of agricultural land (Skole and Tucker 1993, de Jong et al. 2010). Tropical moist forest also has the highest rate of secondary forest succession (de Jong et al. 2010), where woody vegetation regrows after forest clearance, but these secondary forests tend to have low basal area, low variation in stem diameters, an even canopy height, and few large trees, compared to the original old-growth forests (Guariguata and Ostertag 2001). Species richness of birds declines with increasing forest disturbance (Lawton et al. 1998), and bird species that mainly inhabit forests are particularly prone to extinction risk (Şekercioğlu et al. 2004). This makes it imperative to evaluate avian habitat relationships of tropical species dependent on primary, old-growth forest that may be vulnerable to increased forest loss and conversion to secondary forest (Brook et al. 2006, Wright and Muller-Landau 2006a,b).

Almost a third of Psittaciformes (parrots) are currently threatened (BirdLife International 2016a), the majority of which occur in the Neotropics (Olah et al. 2016). Among these, the genus Amazona has the greatest species richness, two-thirds of which are internationally considered threatened (Snyder et al. 2000). The main cause of decline for the majority of threatened Psittaciformes is through anthropogenic impacts of agriculture, capture for trade, and logging, with large-bodied, forestdependent parrot species more likely to be threatened (Olah et al. 2016). Large-bodied parrot species exhibit low population densities, and tend to be associated with primary forests (Marsden 1999, Marsden and Pilgrim 2003, Symes and Marsden 2007, Lee and Marsden 2012). In particular, forest structural characteristics of tree diameter, height, and canopy cover influence psittacine density (Marsden 1992, Evans et al. 2005, Marsden and Symes 2006). Nevertheless, the majority of studies have been conducted on Psittaciformes of Papua New Guinea and the Indonesian islands (Marsden and Royle 2015), and we have very limited information on the response to forest loss of threatened parrot species in tropical moist forests of continental America.

The near-threatened Northern Mealy Amazon (Amazona guatemalae) is one of the largest Amazon parrot species in continental America, and occurs in Mesoamerica from southern Mexico to western Panama (Forshaw 1989, Birdlife International 2016b). Given that the Northern Mealy Amazon has only recently been taxonomically separated from the more widely distributed Southern Mealy Amazon (Amazona farinosa) in South America (Wenner et al. 2012, del Hoyo and Collar 2014), it is essential to determine the status and ecological requirements of the Northern Mealy Amazon in Mesoamerica. However, only one study has been conducted on the Northern Mealy Amazon, which determined that the species undertakes long-distance seasonal movements from the Petén in Guatemala to tropical moist forest in southern Mexico (Bjork 2004).

Forest loss is one of the main factors affecting wild populations of the Northern Mealy Amazon, and in Mesoamerica area of forest cover has declined at an annual rate of $0.5 \%$, with a forest area loss of $4186 \mathrm{~km}^{2}$ per year from 1990-2015 (FAO 2015).
Mexico contains three quarters of Mesoamerican forests, but has experienced the greatest annual decline in forest area (FAO 2015). Notably, in Mexico, the Northern Mealy Amazon has now been extirpated from a large part of its historic range, suffering a $45 \%$ to $46.8 \%$ reduction from its original distribution (Ríos-Muñoz and Navarro-Sigüenza 2009, Monterrubio-Rico et al. 2016).

In the present study, we aimed to evaluate forest metrics associated with density of Northern Mealy Amazons, and determine whether parrots used forest types according to availability in the modified landscape of Los Chimalapas, Mexico. We hypothesized that the large-bodied Northern Mealy Amazon would occur at low density, and be associated with primary tropical moist forest, that is characterized by a high density of large, tall trees. Therefore, specific objectives of our study were the following: (1) to determine density of Northern Mealy Amazons in three forest types of primary evergreen tropical moist forest (evergreen hereafter), primary riparian tropical moist forest (riparian hereafter), and tropical moist forest at various stages of secondary succession (secondary hereafter); (2) to identify differences among forest types in metrics of forest structure and tree species richness; (3) to evaluate relationships of metrics of forest structure and tree species composition with occurrence and number of parrots at point counts; and (4) to determine whether use of forest types by Northern Mealy Amazons differed from availability of forest types in the landscape. In this way, we aimed to identify forest types with high parrot density that are used disproportionately by Northern Mealy Amazons, and forest metrics that influence parrot density, so as to guide management and conservation for this large, threatened parrot species.

\section{METHODS}

\section{Study area}

We conducted the study in the highland region of Los Chimalapas $\left(17^{\circ} 08^{\prime}-17^{\circ} 02^{\prime} \mathrm{N}, 94^{\circ} 38^{\prime}-94^{\circ} 08^{\prime} \mathrm{W}\right.$; Fig. 1) in northeastern Oaxaca, Mexico. The $6000 \mathrm{~km}^{2}$ region of Los Chimalapas is owned and managed by the Zoque indigenous group, and is one of the most biologically diverse areas in Mesoamerica that is largely unstudied (Peterson et al. 2003, Navarro-Sigüenza et al. 2008). Annual rainfall is $2000-4500 \mathrm{~mm}$, with average temperatures $22-26^{\circ} \mathrm{C}$, and a short dry season from March to June (Trejo 2004). The region has an elevation range of $70-1800$ $\mathrm{m}$ asl, where tropical moist forest covers $64 \%$ of the landscape (Martínez-Pacheco 2012).

Los Chimalapas comprises predominantly primary evergreen forest covering $1866.3 \mathrm{~km}^{2}$, with common tree species of Dialium guianense, Terminalia amazonia, and Cojoba arborea (Torres Colín 2004). Primary riparian forest occurs along permanent rivers, mainly below $500 \mathrm{~m}$ asl, and comprised $491.9 \mathrm{~km}^{2}$ of land cover. Common tree species of riparian forest are Ficus sp., Garcinia macrophylla, Vochysia guatemalensis, and Inga vera (Torres Colín 2004). Clearance of primary forest followed by later abandonment of cleared plots has resulted in the regrowth of secondary forests that comprised $120.5 \mathrm{~km}^{2}$ of land cover in Los Chimalapas by 2003 (Martínez-Pacheco 2012). The Northern Mealy Amazon occurs in northern Chimalapas, in the Municipality of Santa Maria Chimalapa, which is located within the tropical moist broadleaf forest biome (Olson et al. 2001). Therefore, we surveyed parrots and measured forest metrics at 
point counts in three forest types of evergreen, riparian, and secondary forest below $600 \mathrm{~m}$ asl, across a $60 \mathrm{~km}$ section of the Municipality of Santa Maria Chimalapa.

Fig. 1. The study area in northern Chimalapas, Mexico, showing the modified tropical moist forest landscape, main rivers (dark lines), and the general location of point counts.

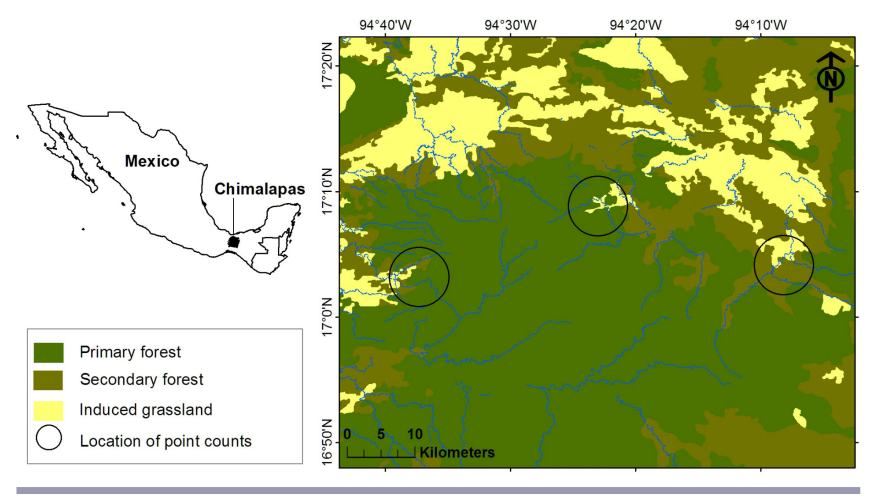

\section{Parrot surveys}

To determine the density of Northern Mealy Amazons in the landscape matrix of Los Chimalapas, we established 120 variable radius point counts, stratified as 60 in primary forest, and 60 in secondary forest. Within the primary forest, we located 33 point counts in tropical evergreen forest and 27 point counts in riparian forest. Point counts were separated by $250 \mathrm{~m}$ to increase independence of counts (Marsden 1999). Reproductive activity of the Northern Mealy Amazon commences in January with nestsite selection and copulation by breeding pairs (Bjork 2004). Nests are initiated in late February with the start of egg-laying, and nesting continues through to early July when the last chicks fledge (Bjork 2004). Therefore, we conducted surveys of parrots in the breeding season of March 2014 and the nonbreeding season of September 2013.

All surveys were conducted by the same observer (MADLH), and each point count was surveyed only once in both the breeding and nonbreeding season. We conducted a 10 min count at each point to increase the likelihood that birds close to the observer were detected (Marsden 1999). We recorded all parrots seen or heard, and noted the number of parrots, form of detection (observation, vocal), whether the parrot was perched, and compass direction of the detection. We also measured distance from the observer to the bird with a Bushnell Yardage Pro 450 range-finder. Surveys were conducted after sunrise and until 10:30 h, which is the period of greatest parrot activity (Marsden 1999).

\section{Forest structure and composition}

At each point count we marked out a $25-\mathrm{m}$ radius circular plot to survey forest structure, and composition in an area of 1963.5 $\mathrm{m}^{2}$ around the point. Within this survey plot we determined the number of trees with diameter at breast height $(\mathrm{dbh}) \geq 10 \mathrm{~cm}$. We considered $10 \mathrm{~cm}$ dbh as the lower limit for trees recorded in our surveys because this is frequently used in forest surveys (Bullock and Solis-Magallanes 1990, Chapman et al. 1994), and large trees are more likely to be used by the Northern Mealy Amazon, which is a large-bodied canopy species (Greenberg 1981, Loiselle 1988,
Bjork 2004). For each tree, we measured dbh at $1.3 \mathrm{~m}$ height using a $10 \mathrm{~m}$ diameter tape, and determined total tree height, and ramification height to the first major branch, using a treemeasuring pole extendable to $15 \mathrm{~m}$ for trees $<15 \mathrm{~m}$ height, and a Criterion RD 1000 digital dendrometer for trees $>15 \mathrm{~m}$ height. Trees that ramify at over half their total height are indicative of having grown in shady closed-canopy conditions of primary forest, whereas trees that ramify at less than half their total height are indicative of having grown in more open conditions of disturbed or secondary forests (Torquebiau 1986). These variables of forest structure could therefore provide an indication of the condition of forests around each point count.

We also identified tree species within each $25-\mathrm{m}$ radius circular plot using reference guides of Pennington and Sarukhán (1998), and Vázquez Torres et al. (2010). Where tree species could not be identified in the field, we collected samples for identification in the Herbario Nacional of the Instituto de Biología, Universidad Nacional Autónoma de México in Mexico City. In particular, we recorded the abundance of tree species used as resources by mealy parrots (A. guatemalae, and A. farinosa) because abundance of tree species used as food or nest-site resources has been found to influence occurrence and density of other parrot species (Kinnaird et al. 2003, Berkunsky et al. 2015). Tree species occurring in Santa Maria Chimalapa that have been reported in the diet or used as nest-sites by mealy parrots (Bjork 2004, Lee et al. 2014) include Terminalia amazonia, Dialium guianense, Ficus sp., Spondias mombin, Ochroma pyramidale, and Sloanea meianthera (Table A1.1).

\section{Statistical analyses}

To ensure that parrots were using the particular forest type, rather than just flying over, we used only records of perched individuals to estimate parrot density per forest type (Marsden 1999). We modeled Northern Mealy Amazon density using the program Distance 6.0 (Thomas et al. 2010), but could only model density estimates for the breeding season because we did not have sufficient records of perched birds to model parrot density in the nonbreeding season. We used the Multiple Covariates Distance Sampling engine of Distance 6.0, both to increase the reliability of density estimates where there may be few observations in a subset of data by forest type, and to enable inferences regarding covariates of forest structure (Marques et al. 2007). We included the forest structure covariates of tree density, mean tree $\mathrm{dbh}$, and mean tree height recorded at each point count. However, we excluded mean tree ramification height to the first major branch because this was strongly correlated with total tree height $(\mathrm{r}=$ $0.81, \mathrm{P}<0.5$ ), and highly correlated variables may lead to bias in density estimates (Marques et al. 2007). Data were not truncated so as to include the greatest number of detections of perched birds. We used a stratification approach to analyze survey data by forest type, which together with the incorporation of covariates, minimizes heterogeneity in detection probabilities (Buckland et al. 2001, Marques and Buckland 2003). We generated Distance models using the half-normal and hazard functions, with cosine and simple polynomial series adjustments, and all combinations of covariates (Table A1.2).

We used Akaike Information Criteria (AIC) to evaluate model fit and complexity (Buckland et al. 2001). We then calculated the difference in AIC of each model with the lowest AIC model 
( $\triangle \mathrm{AIC}$ ), and their Akaike weights (wi), to identify parsimonious candidate models that had $\triangle \mathrm{AIC} \leq 2$ (Burnham and Anderson 2002, Wagenmakers and Farrell 2004). We selected the most appropriate density model based on their AIC wi ratios that may be interpreted as the conditional probability of being the model with best fit to the data (Wagenmakers and Farrell 2004). Finally, we evaluated the importance of each covariate by calculating the sum of AIC wi of all models containing the covariate (Symonds and Moussalli 2011).

We then used the Distance model that had best fit to the data to obtain Northern Mealy Amazon density estimates, and their 84\% confidence intervals, for each forest type. Density estimates were considered to differ significantly among forest types where upper and lower $84 \%$ confidence intervals did not overlap because this robustly mimics the 0.05 probability obtained from statistical tests (Payton et al. 2003, MacGregor-Fors and Payton 2013).

To determine whether forest types differed in species richness and forest structure around point counts, we compared metrics of tree species richness, tree density, mean tree dbh, mean tree height, and mean ramification height among evergreen, riparian, and secondary forests. Data did not present a normal distribution, therefore we applied Kruskal-Wallis ANOVA to compare metrics among forest types. Where significant differences were detected, we applied Dunn posthoc analysis to determine which forest type contributed the significant difference (Zar 1999). We also calculated the Morisita index of similarity to compare the abundance of each tree species among the three forest types (Krebs 1999).

To evaluate relationships of the complete set of forest structure and tree species composition metrics with occurrence and number of parrots recorded at point counts, we first used principal component analysis (PCA) to convert 11 forest metrics to a reduced set of composite axes. These included four forest structure variables of tree density, mean dbh, mean tree height, and mean ramification height, as well as seven floristic composition variables of tree species richness, and the abundance of each of the six common tree species used as resources by mealy parrots (T. amazonia, D. guianense, Ficus sp., S. mombin, O. pyramidale, and $S$. meianthera). We retained only the principal components with eigenvalues $>1$, which were incorporated as predictor variables in generalized additive models (GAMs) to evaluate their relationships with number of parrots and presence/ absence of parrots at point counts. We used GAMs because these are less restrictive, generating nonlinear response curves that are modeled as a series of additive smoothing functions dictated by the data (Hastie and Tibshirani 1986). This is more suited to deal with nonlinear complex relationships that may occur in nature. We fitted penalized cubic regression splines to the data to control complexity of the curve (degrees of freedom) and avoid overfitting (Wood 2006). We used the mgcv package in $\mathrm{R}$ (Wood 2011, R Core Team 2016) to run Poisson GAMs to model the relationship with number of parrots recorded at point counts, and binomial GAMs to model the presence/absence of parrots perched within a $50-\mathrm{m}$ radius of the point count. We identified the model with lowest AIC as having the best fit to the data (Buckland et al. 2001), and calculated $\triangle \mathrm{AIC}$ and AIC wi to identify competing models (Burnham and Anderson 2002), and their conditional probability of being the best-fitting model (Wagenmakers and Farrell 2004).
Finally, to determine whether use of forest types by Northern Mealy Amazons differed from that expected by availability, we applied $G$-test to compare the number of parrots recorded in each forest type with the number of parrots expected based on availability of forest types. For observed use in each forest type, we considered only parrots perched within a 50-m radius around each point count. We determined proportional availability of each forest type using estimates of land-cover area determined for Los Chimalapas by Martínez-Pacheco (2012) based on 28.5-m resolution Landsat ETM satellite images from 2000-2003. We calculated riparian forest cover considering a $50-\mathrm{m}$ band-width at each side of permanent rivers in the region, which were overlaid from a hydrogeological map of 1:250,000 (INEGI 2012) using the QGIS 2.12 Geographic Information System (QGIS Development Team 2015). To obtain the expected number of parrots in each forest type, we multiplied the total number of parrots recorded over all forest types by the proportional land cover of each forest type. This gave the number of parrots that would be expected in each forest type based on the proportional availability of that forest type in the landscape, which was compared with the observed number of parrots recorded in each forest type.

To determine whether a particular forest type was used by parrots significantly more than expected, we generated simultaneous Bonferroni confidence intervals for the proportional use observed for each forest type, applying an alpha adjusted to $\mathrm{P}<0.017$ for the set of three forest types (Nue et al. 1974, Byers et al. 1984). Utilization differs significantly when the expected proportion of use based on availability falls outside the adjusted alpha confidence interval of actual use (Byers et al. 1984), with the resource category being used either more or less than expected by availability. All statistical analyzes were carried out using R version 3.3.0 ( $\mathrm{R}$ Core Team 2016). Descriptive statistics are presented as mean with standard deviation, except where stated, and we considered $\mathrm{P}<0.05$ as significantly different in statistical analysis.

\section{RESULTS}

\section{Parrot density}

We obtained 133 detections of Northern Mealy Amazons in Los Chimalapas, although the majority of these were obtained during the breeding season with a total of 128 detections in March 2014, compared to only 5 detections during the nonbreeding season of September 2013. During the breeding season, detections were made at a mean distance of $47.7 \pm 28.9 \mathrm{~m}$ (range $=17-120 \mathrm{~m}$, $\mathrm{n}=29)$ in evergreen forest, $37.8 \pm 22.2 \mathrm{~m}$ (range $=4-90 \mathrm{~m}, \mathrm{n}=$ 46) in riparian forest, and $85.8 \pm 57.9 \mathrm{~m}$ (range $=5-254 \mathrm{~m}, \mathrm{n}=$ 53 ) in secondary forest. We recorded a mean $3.1 \pm 3.6$ parrots per 10 min point count in the breeding season, with a mean group size of $2.8 \pm 2.3$ parrots (range $=1-12$ parrots). By comparison, parrots were largely absent from the study site during the nonbreeding season, recording an average of only $0.15 \pm 1.0$ parrots per 10 min point count in September 2013, with a mean group size of $4.6 \pm 2.9$ parrots (range $=2-9$ parrots).

We obtained three candidate Distance models that had $\Delta \mathrm{AIC} \leq 2$ for density of Northern Mealy Amazons during the breeding season (Table A1.2). Of these, the model with lowest AIC and coefficient of variation $(25.6 \%)$ included the two covariates of tree density and mean tree height, and was generated using the 
Table 1. Multiple-covariates Distance Sampling model parameters for density estimates to $84 \%$ confidence intervals of Northern Mealy Amazons (Amazona guatemalae) during the breeding season (March 2014) in Los Chimalapas, Mexico.

\begin{tabular}{|c|c|c|c|c|c|}
\hline Stratum & $\begin{array}{l}\text { Number of } \\
\text { point counts }\end{array}$ & $\begin{array}{c}\text { Mean density (ind/ } \\
\mathrm{km}^{2} \pm \mathrm{SE} \text { ) }\end{array}$ & $\begin{array}{l}\text { Mean cluster size } \\
\quad \text { (ind } \pm \mathrm{SE} \text { ) }\end{array}$ & $\begin{array}{c}\text { Mean density of cluster } \\
\left.\text { (ind } / \mathrm{km}^{2} \pm \mathrm{SE}\right)\end{array}$ & $\begin{array}{c}\text { Effective detection radius }(\mathrm{m}) \pm \\
\text { SE }\end{array}$ \\
\hline Global & 120 & $19.5 \pm 6.2$ & $2.8 \pm 0.2$ & $6.3 \pm 2.9$ & $61.7 \pm 4.7$ \\
\hline Evergreen forest & 33 & $18.9 \pm 5.7$ & $4 \pm 0.5$ & $4.7 \pm 1.2$ & $57.8 \pm 5.5$ \\
\hline Riparian forest & 27 & $35.9 \pm 8.7$ & $2.8 \pm 0.3$ & $12.6 \pm 2.6$ & $55.5 \pm 4.3$ \\
\hline Secondary forest & 60 & $3.4 \pm 0.8$ & $2.1 \pm 0.2$ & $1.5 \pm 0.3$ & $73.5 \pm 5.3$ \\
\hline
\end{tabular}

half-normal probability function with cosine adjustment (Table A1.2). This model was 2.0 and 2.4 times more likely to be the best explanation for parrot density compared with the second and third models, respectively. Furthermore, this best-fitting model incorporated the two covariates with greatest weight over all models, where the most important covariate was mean tree height (sum AIC $w i=0.87$ ), followed by mean tree density (sum AIC $w i$ $=0.65$ ). By comparison, mean tree dbh was not included in the best-fitting model, and had lower importance in the models (sum AIC $w i=0.41)$.

The best-fitting Distance model estimated an overall mean density of $19.5 \pm 6.2$ Northern Mealy Amazons $/ \mathrm{km}^{2}$ (84\% CI: $\left.13.5-28.1\right)$ during the breeding season (Table 1). Density estimates of parrots were significantly higher in both types of primary forest, with 18.9 \pm 5.7 parrots $/ \mathrm{km}^{2}(84 \% \mathrm{CI}: 12.5-28.9)$ in evergreen forest, and $35.9 \pm 8.7$ parrots $/ \mathrm{km}^{2}$ (84\% CI: $\left.25.6-50.5\right)$ in riparian forest, compared to only $3.4 \pm 0.8$ parrots $/ \mathrm{km}^{2}(84 \% \mathrm{CI}: 2.5-4.8)$ in secondary forest (Fig. 2).

Fig. 2. Northern Mealy Amazon (Amazona guatemalae) density estimates with $84 \%$ confidence intervals in evergreen, riparian, and secondary tropical moist forest in Los Chimalapas, Mexico, during the breeding season of March 2014.

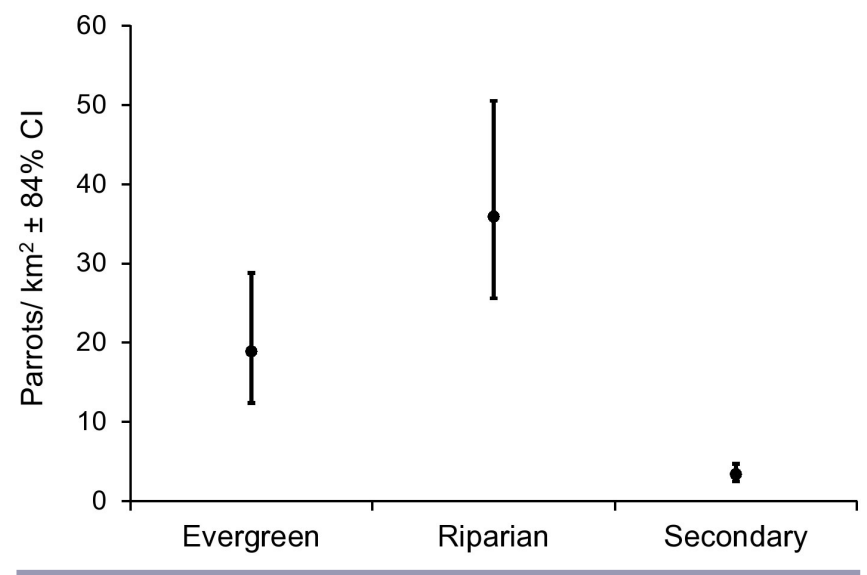

\section{Forest structure and composition}

Forest structure within a $25-\mathrm{m}$ radius of point counts differed significantly among forest types (Fig. 3). Secondary forest had significantly fewer trees $\left(\mathrm{H}_{2}=62.7, \mathrm{P}<0.001\right.$; Fig. 3A) than evergreen $(\mathrm{q}=5.0, \mathrm{P}<0.001)$ and riparian $(\mathrm{q}=7.4, \mathrm{P}<0.001)$ forests, where tree density was $47 \%$ and $63 \%$ lower in secondary forest compared to evergreen and riparian forest, respectively
(Fig. 3A). Tree density also differed significantly between the two primary forest types $(\mathrm{q}=2.5, \mathrm{P}<0.05)$, being $31 \%$ higher in riparian compared to evergreen forest (Fig. 3A). Moreover, forest types differed in mean tree $\mathrm{dbh}\left(\mathrm{H}_{2}=18.8, \mathrm{P}<0.001\right.$; Fig. 3B), total height $\left(\mathrm{H}_{2}=40.8, \mathrm{P}<0.001\right.$; Fig. $\left.3 \mathrm{C}\right)$, and ramification height $\left(\mathrm{H}_{2}=54.3, \mathrm{P}<0.001\right.$; Fig. 3D). In all cases, secondary forest differed from the two primary forest types (Fig. 3), having trees with $22 \%$ and $10 \%$ smaller dbh, respectively (Evergreen: $\mathrm{q}$ $=4.3, \mathrm{P}<0.001$, Riparian: $\mathrm{q}=2.0, \mathrm{P}<0.05)$, of $32 \%$ and $16 \%$ lower total height (Evergreen: $\mathrm{q}=6.4, \mathrm{P}<0.001$, Riparian: $\mathrm{q}=$ $2.8, \mathrm{P}<0.01$ ), and $51 \%$ and $41 \%$ lower ramification height (Evergreen: $\mathrm{q}=6.9, \mathrm{P}<0.001$, Riparian: $\mathrm{q}=4.8, \mathrm{P}<0.001$ ). Furthermore, within primary forest, trees in evergreen forest had significantly greater total height $(\mathrm{q}=2.9, \mathrm{P}<0.01)$, being $19 \%$ taller than trees in riparian forest (Fig. 3C).

Fig. 3. Variation among forest types in metrics of trees $(\geq 10 \mathrm{~cm}$ $\mathrm{dbh}$ ) within a 25-m radius of point counts for (A) tree density in $0.2 \mathrm{ha},(\mathrm{B})$ tree diameter at breast height $(\mathrm{cm}),(\mathrm{C})$ total tree height (m), (D) ramification height to the first major branch (m), and (E) tree species richness, in tropical moist forest of Los Chimalapas, Mexico. Mean values per point count with $95 \%$ confidence intervals are shown. Letters indicate significantly different Dunn posthoc pairwise comparisons among forest types.
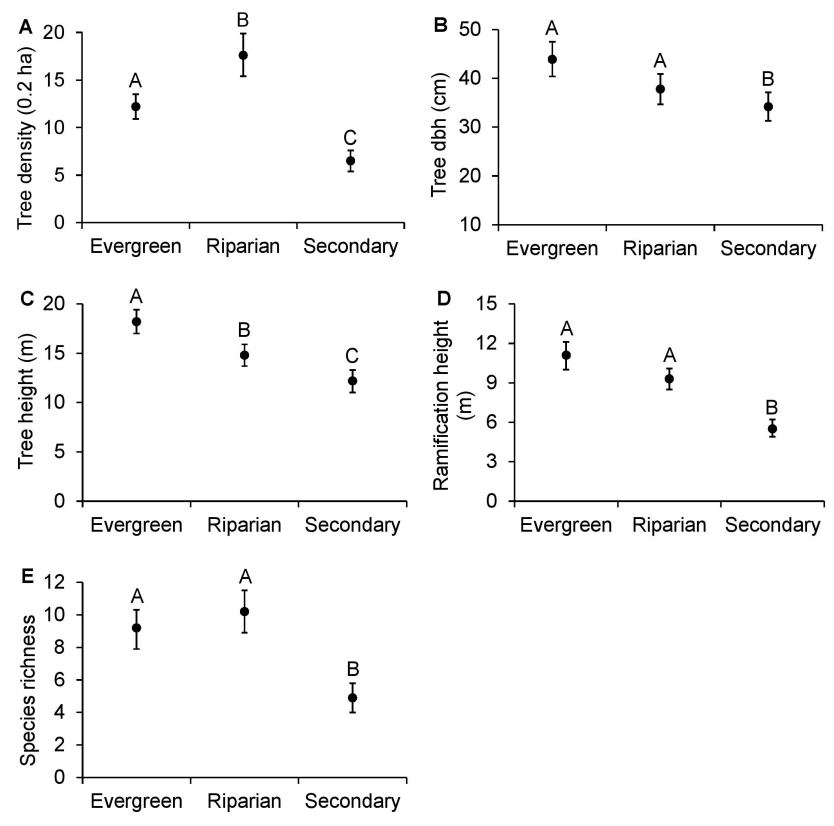
Species richness of trees was also significantly lower in secondary forest $\left(\mathrm{H}_{2}=42.6, \mathrm{P}<0.001\right)$, with $47 \%$ fewer species than evergreen forest $(\mathrm{q}=5.6, \mathrm{P}<0.001)$, and $52 \%$ fewer species than riparian $(\mathrm{q}=4.9, \mathrm{P}<0.001)$ forest $($ Fig. 3E). Tree species composition was similar between evergreen and riparian forest (Morisita $=0.66$ ), whereas secondary forest differed in species composition compared to evergreen (Morisita $=0.42$ ) and riparian (Morisita $=0.46$ ) forest. The most abundant tree species in evergreen forest were Terminalia amazonia and Dialium guianense (Fig. 4A), and these were also among the most abundant tree species in riparian forest (Fig. 4B). By comparison, the most common tree species in secondary forest was the fast-growing Schizolobium parahyba (Fig. 4C).

Fig. 4. Proportional abundance of tree species within a 25-m radius of point counts in (A) evergreen, (B) riparian, and (C) secondary tropical moist forest in Los Chimalapas, Mexico. Only tree species contributing $>5 \%$ of tree abundance in each forest type are shown.
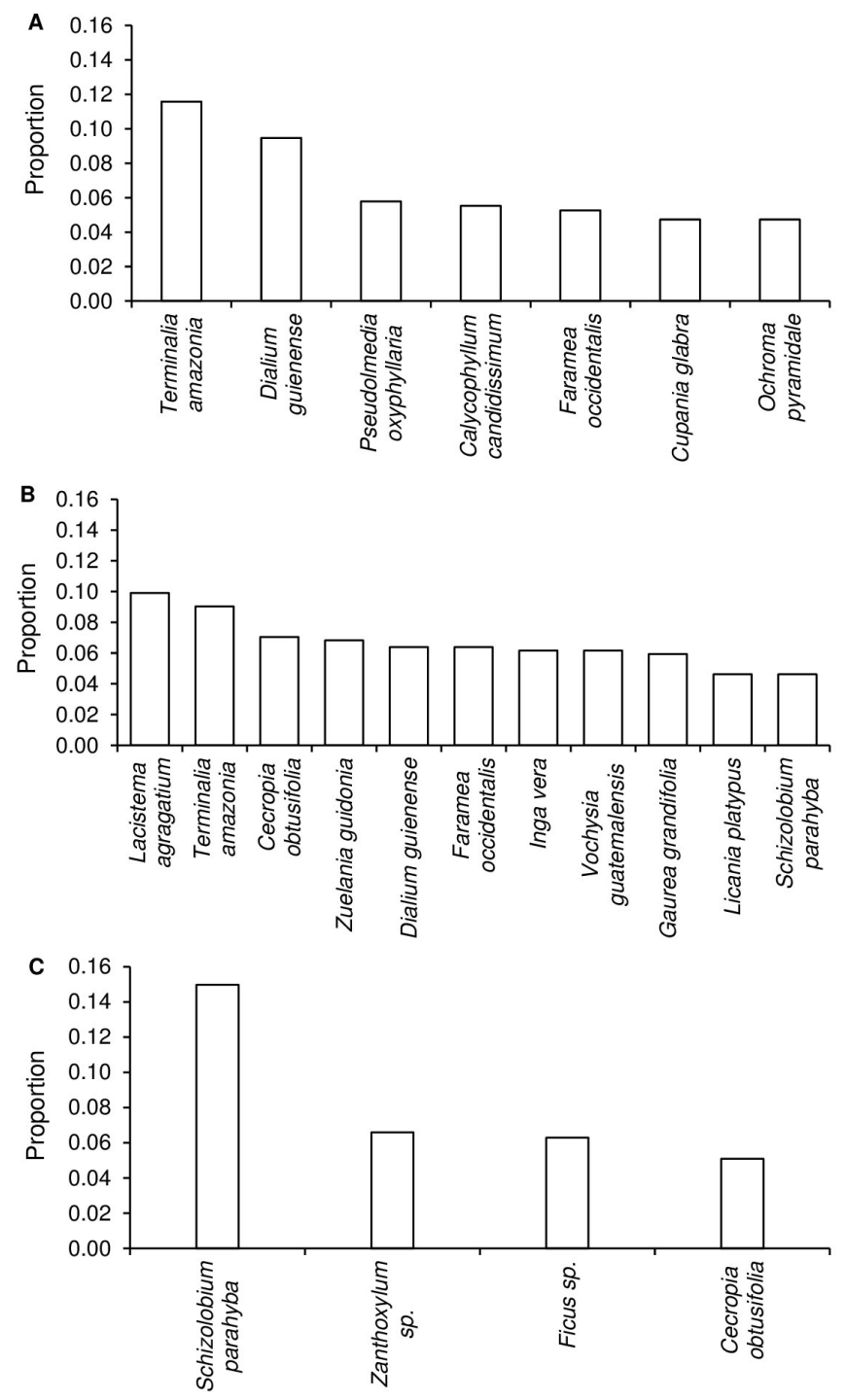

\section{Relationship of forest metrics with parrot occurrence}

The 11 forest structure and composition variables were reduced to three principal components that explained $94.7 \%$ of the variation (Table 2). Principal Component 1 explained $63.3 \%$ of the variance, and the variable with greatest weight was mean tree $\mathrm{dbh}(\mathrm{r}=0.93$; Table 2). Principal Component 2 explained $25.2 \%$ of the variance, and was influenced by tree density $(r=0.81$; Table 2). Finally, Principal Component 3 explained only $6.2 \%$ of variance, and was mainly influenced by mean tree height $(\mathrm{r}=0.71$; Table 2).

Table 2. Principal components analysis of forest structure and floristic composition variables within a $25-\mathrm{m}$ radius of point counts in tropical moist forest of Los Chimalapas, Mexico ( $r>$ 0.7 marked in bold font).

\begin{tabular}{lccc}
\hline \hline & Component & Component & Component \\
& 1 & 2 & 3 \\
\hline Eigenvalue & 3.7 & 1.9 & 1.2 \\
\% Explained & 63.3 & 25.2 & 6.2 \\
Correlations with individual variables & & \\
Mean tree diameter at & $\mathbf{0 . 9 3}$ & 0.23 & 0.27 \\
breast height & & & \\
Tree density & 0.12 & $\mathbf{0 . 8 1}$ & 0.16 \\
Mean tree height & 0.28 & 0.14 & $\mathbf{0 . 7 1}$ \\
Mean ramification height & 0.19 & 0.25 & 0.49 \\
Species richness & 0.07 & 0.44 & 0.36 \\
Terminalia amazonia & 0.04 & 0.06 & -0.05 \\
Dialium guianense & 0.04 & 0.08 & -0.05 \\
Ficus sp. & $(-)$ & $(-)$ & 0.06 \\
Spondias mombin & $(+)$ & -0.01 & 0.02 \\
Ochroma pyramidale & $(-)$ & $(+)$ & -0.08 \\
Sloanea meianthera & $(-)$ & -0.03 & 0.02 \\
\hline
\end{tabular}

Poisson GAMs for number of parrots recorded at point counts revealed a single candidate model, which incorporated all three principal components, and this model explained $73.8 \%$ of the deviance (Table A1.3a). Therefore, abundance of Northern Mealy Amazons at point counts during the breeding season was most likely influenced by forest structure of a high density of large, tall trees.

Binomial GAMs for presence/absence of parrots perched within a 50-m radius of the point count revealed two candidate models (Table A1.3b). The first model included all three principal components and explained $34.9 \%$ of deviance (Table A1.3b), with a $53 \%$ likelihood of being the best model. A competing model comprised principal Components 1 and 2 and explained 29.5\% of deviance (Table A1.3b), and had an almost equal $45 \%$ likelihood of being the best model. However, the first model including all three principal components was 1.2 times more likely to provide the best fit for parrot occurrence compared with the second model containing only the first two principal components. Therefore, parrots may be more likely to perch within $50 \mathrm{~m}$ of a point count in forest with a high density of large trees.

Finally, use of forest types by Northern Mealy Amazons differed significantly from that expected by availability of forest types in the landscape $\left(G_{2}=39, P<0.001\right)$. Almost all records of Northern Mealy Amazons perched within $50 \mathrm{~m}$ of point counts occurred 
in primary forest ( $94 \%$ of perched birds), with very few parrots $(6 \%)$ recorded within $50 \mathrm{~m}$ of point counts in secondary forest (Table 3). In particular, parrots were most frequently recorded in primary riparian forest ( $54 \%$ of perched birds), and used this forest type more than expected by availability (Table 3 ).

Table 3. Proportional availability and use of three forest types by Northern Mealy Amazons, with Bonferroni confidence intervals, in tropical moist forest of Los Chimalapas, Mexico, during the breeding season of March 2014. ${ }^{*}=\mathrm{P}<0.05$

\begin{tabular}{lccc}
\hline \hline Forest type & $\begin{array}{c}\text { Proportion } \\
\text { available }\end{array}$ & $\begin{array}{c}\text { Proportion } \\
\text { used }\end{array}$ & $\begin{array}{c}\text { Bonferroni confidence } \\
\text { intervals }\end{array}$ \\
\hline Evergreen forest & 0.75 & 0.40 & $0.26 \leq$ obs $\leq 0.55^{*}$ \\
Riparian forest & 0.20 & 0.54 & $0.39 \leq$ obs $\leq 0.68^{*}$ \\
Secondary forest & 0.05 & 0.06 & $0.00 \leq$ obs $\leq 0.13$ \\
\hline
\end{tabular}

\section{DISCUSSION}

\section{Parrot density}

During the breeding season we recorded an overall density of 19.5 \pm 6.2 Northern Mealy Amazons $/ \mathrm{km}^{2}$ in the tropical moist forest of Los Chimalapas, Mexico, with greatest density in primary forest. This is relatively high compared to other large-bodied parrots that have density estimates of less than 14 individuals $/ \mathrm{km}^{2}$ (Symes and Marsden 2007, Lee and Marsden 2012), and is higher than the density estimate of 13.6 parrots $/ \mathrm{km}^{2}$ for the Southern Mealy Amazon in tropical moist forest of South America (Lee and Marsden 2012). By comparison, high densities of $22.5-29$ parrots $/ \mathrm{km}^{2}$ are usually recorded for smaller parrot species (Marsden and Symes 2006). The unexpectedly high density of Northern Mealy Amazons in tropical moist forest of Los Chimalapas during the breeding season highlights the importance of the region for this threatened species. Therefore, large tracts of tropical moist forest such as Los Chimalapas may be biologically important not only for their high biodiversity (Peterson et al. 2003), but also because they support high densities of threatened species.

Notably, Northern Mealy Amazons were almost absent from Los Chimalapas during the nonbreeding season, with such low encounter rates that it was not possible to model density estimates. Various studies have reported seasonal variation in abundance of psittacines (Renton 2002, Karubian et al. 2005, Lee and Marsden 2012), suggesting that parrots make seasonal movements among areas. Bjork (2004) also recorded a decline in relative abundance of the Northern Mealy Amazon during the nonbreeding season in the Petén of Guatemala, and showed that Northern Mealy Amazons undertake migrations of $138 \pm 61.9 \mathrm{~km}$ from the Petén in Guatemala to Campeche and Chiapas in Mexico. Therefore, it is highly likely that Northern Mealy Amazons in Los Chimalapas are undertaking similar long-distance migrations during the nonbreeding season to potential alternative sites of El Ocote (80 $\mathrm{km})$ or La Sepultura Biosphere Reserve $(135 \mathrm{~km})$ in Chiapas. Future research could apply radio-telemetry techniques (Bjork 2004) to identify alternate migration sites used by Northern Mealy Amazons in Mexico.

We also determined spatial variation in Northern Mealy Amazon density with a low density of parrots in secondary forest. Other studies have demonstrated lower parrot densities in human modified forests. Marsden and Pilgrim (2003) found lower densities of the Blue-eyed Cockatoo (Cacatua ophthalmica) in disturbed forests on Papua New Guinea, and Kinnaird et al. (2003) determined higher densities of the Salmon-crested Cockatoo (Cacatua moluccensis) in primary forests with high basal area and canopy closure. Similarly, Karubian et al. (2005) found that relative abundance of large macaws declined with increasing levels of human activity and landscape modification. These studies all relate to large parrot species, and along with the results obtained for the Northern Mealy Amazon, suggest that large threatened parrot species in particular may be more closely associated with primary forests.

\section{Factors influencing use of forest types by parrots}

Northern Mealy Amazons in Los Chimalapas were more frequently recorded within $50-\mathrm{m}$ of point counts in primary evergreen and riparian forests during the breeding season, and used riparian forests significantly more than expected by availability, whereas parrots were rarely encountered in secondary forest. This corresponds with the findings of Bjork (2004) for the Northern Mealy Amazon in the Petén of Guatemala, who determined greater relative abundance of Northern Mealy Amazons in primary forest, whereas parrots were rarely observed perched in secondary forest. These results provide further support that the Northern Mealy Amazon is a primary forest specialist throughout its range in Mesoamerica.

Furthermore, the occurrence and number of parrots perched within a 50-m radius of point counts was predicted by the density of large, tall trees around the point count. This is similar to studies in lowland Atlantic forest of Brazil where use of selectively logged forests by two Amazon parrot species was associated with large trees (Marsden et al. 2000). Legault et al. (2011) also found that presence of three parrot species in New Caledonia is related to canopy cover, where parrots selected areas with $80-100 \%$ canopy cover, avoiding areas with less than $20 \%$ canopy cover. Density of large trees was the main environmental variable influencing the abundance of avian species associated with primary tropical wet forest in Malaysia (Peh et al. 2005). Our results therefore indicate that during the breeding season Northern Mealy Amazons are strongly associated with primary forests where there is a greater density of canopy trees.

\section{Comparison with Southern Mealy Amazon}

The high seasonal fluctuation in abundance of Northern Mealy Amazons in Los Chimalapas, Mexico, corresponds with a similar seasonal fluctuation in abundance of Northern Mealy Amazons in the Petén of Guatemala (Bjork 2004). By comparison, Lee and Marsden (2012) recorded only slight seasonal variation in density of the Southern Mealy Amazon in floodplain forest of Southeast Peru. Therefore, it may be that the Northern Mealy Amazon in Mesoamerica exhibits greater seasonality in use of forest areas compared to the Southern Mealy Amazon in the Amazonian forests of South America.

Humid forests in Mesoamerica demonstrate marked seasonality in fruiting phenology, generally with peak fruit production during the dry season and in the transition from dry to wet season, while in South America the variation in fruiting phenology is less marked (Morellato et al. 2013). Given the high seasonality in fruit 
production of Central American forests, animal species that depend on these resources need to track fluctuations in resource abundance (Leighton and Leighton 1983, Fleming 1992). This could potentially lead to seasonal movements by the Northern Mealy Amazon in Central America, and Bjork (2004) determined that the seasonal decrease in abundance of Northern Mealy Amazons in Guatemala was associated with a corresponding decline in fruit production, suggesting that parrots make movements in search of food resources.

The Northern Mealy Amazon may also be facing greater pressures of forest loss resulting from anthropogenic activities compared to the Southern Mealy Amazon. In Mesoamerica, tropical moist forest is becoming increasingly fragmented (Holzman 2008). Added to which, the Northern Mealy Amazon has large area requirements making seasonal movements over an area of 10,000 $\mathrm{km}^{2}$ (Bjork 2004). The dependence of Northern Mealy Amazons on primary tropical moist forest, and their high seasonality in abundance and use of areas, emphasizes the need to conserve tracts of continuous primary tropical moist forest for the Northern Mealy Amazon in both breeding and migration areas.

\section{Implications of tropical moist forest conversion}

The results of our study demonstrate the importance of primary tropical moist forest, and in particular riparian forest, for the large-bodied Northern Mealy Amazon during the breeding season. Within the modified landscape of Los Chimalapas, secondary forest had distinct structural and floristic characteristics to primary forest, with a low density of smaller trees of lower tree and ramification height, indicative of trees of disturbed or regenerating forests (Torquebiau 1986). Secondary forests also had lower tree species richness and distinct species composition to that of primary evergreen and riparian forests. Hence, conversion of primary forest to secondary forest may have a negative effect on the status of Northern Mealy Amazon populations in the wild, as determined for the Carnaby's Cockatoo (Zanda latirostris) in the wheatbelt of Western Australia, which was unable to exploit dispersed food resources in fragmented landscapes resulting in eventual extirpation of the species (Saunders 1990). Tropical moist forests have the greatest rate of biomass loss of all forest types in Mexico and present the highest increment in secondary forests (de Jong et al. 2010). This may be detrimental to Northern Mealy Amazon populations in the long-term because secondary forest had significantly lower densities of Northern Mealy Amazons. It should be noted however, that forest metrics associated with population density are not necessarily indicative of high fecundity (van Horne 1983), therefore we also require information on the reproductive output of Northern Mealy Amazons to evaluate the respective quality of each forest type for parrots.

Anthropogenic activities of clearing for agriculture or cattle grazing have been the main cause of primary forest loss in Los Chimalapas (Martínez-Pacheco 2012). Over the period of 2000 2003 , there was an overall loss of $22 \mathrm{~km}^{2}$ of tropical moist forest in the region, whereas the area dedicated to pasture lands increased by $29 \mathrm{~km}^{2}$ (Martínez-Pacheco 2012). As for the majority of Mexico's forests, tropical moist forest in Los Chimalapas is owned by the local community with rights to exploit and sell timber and forest products (Bray et al. 2005). No legally protected areas exist within Los Chimalapas, and a recent proposal for the area to be considered a community ecological reserve was rejected by the Mexican government (Anaya and Álvarez 1994). This makes it imperative to establish community-based forest conservation and management strategies to maintain tropical forest resources and biodiversity in Los Chimalapas.

\section{CONCLUSIONS}

Understanding the requirements of large threatened parrot species such as the Northern Mealy Amazon is essential to develop appropriate strategies for forest management and conservation, and to assess the potential impact of anthropogenic activities on parrot populations in modified landscapes. Largebodied, frugivorous, canopy species are among the avian species unlikely to persist in modified forests (Peh et al. 2005), however, almost nothing is known of the ecological requirements of the Northern Mealy Amazon in Mesoamerica. The results of our study in Mexico, and that of Bjork (2004) in Guatemala, both suggest that the Northern Mealy Amazon is a primary forest specialist that exhibits marked seasonality in use of forest areas. Therefore, the Northern Mealy Amazon in Central America may present important differences in ecological requirements from that of the Southern Mealy Amazon in South America. Northern Mealy Amazons are also under increased pressure from forest loss and capture for the pet trade, making their populations especially vulnerable, and in need of immediate evaluation, and possible status reclassification.

Los Chimalapas in Mexico, and Petén in Guatemala, represent some of the largest tracts of primary tropical moist forest in Mesoamerica. However, both regions are suffering high rates of forest loss (Martínez-Pacheco 2012, Hodgdon et al. 2015), further reducing the availability of primary tropical moist forest for the Northern Mealy Amazon. As determined in our study, the increased conversion of primary tropical moist forest to secondary forest (de Jong et al. 2010) is likely to lead to reduced densities of large, threatened species such as the Northern Mealy Amazon. Brook et al. (2006) argue that afforestation via secondary forest succession may be a poor substitute for primary forest, particularly for the fraction of species that depend on primary old-growth forest, and do not persist in disturbed tropical forest (Peh et al. 2005). This makes it essential to implement strategies and incentives to conserve primary tropical moist forest in relatively undisturbed regions such as Los Chimalapas (Peterson and Navarro Sigüenza 2016), and reduce the rate of conversion to secondary forest, if we are to maintain populations of large forest-dependent species in the long term.

Responses to this article can be read online at: http://www.ace-eco.org/issues/responses.php/957

\section{Acknowledgments:}

The study was conducted in partial fulfillment of a PhD degree by MADLH at the Posgrado en Ciencias Biológicas, of the Universidad Nacional Autónoma de México (UNAM). Funding 
for the research was provided by the Programa de Apoyo a Proyectos de Investigación e Innovación Tecnológica (UNAM-DGAPAPAPIIT grant IN205716) to KR. MADLH received a Doctoral studies grant from the Consejo Nacional de Ciencia y Tecnología (Conacyt 215549). We are grateful to Idea Wild who provided field equipment, and to Patricia Escalante for logistical support. The Secretaria del Medio Ambiente y Recursos Naturales in Mexico provided research permits for the study. We are grateful to the authorities of the Santa Maria Chimalapa municipality for permission to work on their community lands, and to the local people of San Francisco La Paz, San Antonio Nuevo Paraíso, and Chalchijapa who provided assistance in the field. We thank Marisela Martinez Ruiz for assistance in producing a map of the study site, Ruth Rodriguez Tejeda for advice on statistical analyses in $R$, and Alvaro Campos for assistance with taxonomic identification of tree species. We appreciate the constructive comments of the anonymous reviewers and subject editor that helped us to improve the manuscript.

\section{LITERATURE CITED}

Anaya, A. L., and M. Álvarez. 1994. Plan de desarrollo y conservación de una reserva campesina en Los Chimalapas. Instituto Nacional de Ecología, Mexico City, Mexico. [online] URL: http://www.inecc.gob.mx/descargas/publicaciones/28.pdf

Berkunsky, I., M. V. Simoy, R. E. Cepeda, C. Marinelli, F. P. Kacoliris, G. Daniele, A. Cortelezzi, J. Diáz, J. Mateo Friedman, and R. M. Aramburú. 2015. Assessing the use of forest islands by parrot species in a Neotropical savanna. Avian Conservation and Ecology 10(1):11. http://dx.doi.org/10.5751/ACE-00753-100111

BirdLife International. 2016a. BirdLife data zone. BirdLife International, Cambridge, UK. [online] URL: http://datazone. birdlife.org/userfiles/file/Species/Taxonomy/BirdLife_Checklist_Version_90.zip

BirdLife International. 2016b. Species factsheet: Amazona guatemalae. BirdLife International, Cambridge, UK. [online] URL: http://datazone.birdlife.org/species/factsheet/45430583

Bjork, R. D. 2004. Delineating pattern and process in tropical lowland: Mealy Parrot migration dynamics as a guide for regional conservation planning. Dissertation. Oregon State University, Corvallis, Oregon, USA. [online] URL: http://ir.library. oregonstate.edu/xmlui/handle/1957/10842

Bray, D. B., L. Merino-Pérez, and D. Barry. 2005. Community managed in the strong sense of the phrase: the community forest enterprises of Mexico. Pages 3-26 in D. B. Bray, L. Merino-Peréz, and D. Barry, editors. The community forests of Mexico, managing for sustainable landscapes. University of Texas Press, Austin, Texas, USA.

Brook, B. W., C. J. A. Bradshaw, L. P. Koh, and N. S. Sodhi. 2006. Momentum drives the crash: mass extinction in the tropics. Biotropica 38:302-305. http://dx.doi.org/10.1111/j.1744-7429.2006.00141. $\mathrm{x}$

Buckland, S. T., D. R. Anderson, K. P. Burnham, J. L. Laake, D. L. Borchers, and L. Thomas. 2001. Introduction to distance sampling: estimating abundance of biological populations. Oxford University Press, New York, New York, USA.
Bullock, S. H., and J. A. Solis-Magallanes. 1990. Phenology of canopy trees of a tropical deciduous forest in Mexico. Biotropica 22:22-35. http://dx.doi.org/10.2307/2388716

Burnham, K. P., and D. R. Anderson. 2002. Model selection and multimodel inference: a practical information-theoretic approach. Second edition. Springer-Verlag, New York, New York, USA. http://dx.doi.org/10.1007/b97636

Byers, C. R., R. K. Steinhorst, and P. R. Krausman. 1984. Clarification of a technique for analysis of utilization-availability data. Journal of Wildlife Management 48:1050-1053. http://dx. doi.org/10.2307/3801467

Chapman, C. A., R. Wrangham, and L. J. Chapman. 1994. Indices of habitat-wide fruit abundance in tropical forests. Biotropica 26:160-171. http://dx.doi.org/10.2307/2388805

de Jong, B., C. Anaya, O. Masera, M. Olguín, F. Paz, J. Etchevers, R. D. Martínez, G. Guerrero, and C. Balbontín. 2010. Greenhouse gas emissions between 1993 and 2002 from land-use change and forestry in Mexico. Forest Ecology and Management 260:1689-1701. http://dx.doi.org/10.1016/j.foreco.2010.08.011

del Hoyo, J., and N. J. Collar. 2014. Illustrated checklist of the birds of the world. Volume 1. Lynx Editions, Barcelona, Spain.

Evans, B. E. I., J. Ashley, and S. J. Marsden. 2005. Abundance, habitat use, and movements of Blue-winged Macaws (Primolius maracana) and other parrots in and around an Atlantic Forest Reserve. Wilson Bulletin 117:154-164. http://dx.doi.org/10.1676/04-026

Fleming, T. H. 1992. How do fruit- and nectar-feeding birds and mammals track their food resources? Pages 355-391 in M. D. Hunter, T. Ohgushi, and P. W. Price, editors. Effects of resource distribution on animal-plant interactions. Academic, San Diego, California, USA. http://dx.doi.org/10.1016/B978-0-08-091881-5.50015-3

Food and Agriculture Organization of the United Nations (FAO). 2015. Global forest resources assessment 2015. FAO, Rome, Italy. [online] URL: http://www.fao.org/3/a-i4808e.pdf

Forshaw, J. M. 1989. Parrots of the world. Lansdowne Editions, Melbourne, Australia. http://dx.doi.org/10.1515/9781400836208

Greenberg, R. 1981. The abundance and seasonality of forest canopy birds on Barro Colorado Island, Panama. Biotropica 13:241-251. http://dx.doi.org/10.2307/2387802

Guariguata, M. R., and R. Ostertag. 2001. Neotropical secondary forest succession: changes in structural and functional characteristics. Forest Ecology and Management 148:185-206. http://dx.doi.org/10.1016/S0378-1127(00)00535-1

Hastie, T., and R. Tibshirani. 1986. Generalized additive models. Statistical Science 1:297-310. [online] URL: http://www.jstor.org/ stable/2245459 http://dx.doi.org/10.1214/ss/1177013604

Hodgdon, B. D., D. Hughell, V. H. Ramos, and R. B. McNab. 2015. 2000-2013 deforestation trends in the Maya Biosphere Reserve, Guatemala. Rainforest Alliance, New York, New York, USA. [online] URL: http://www.rainforest-alliance.org/sites/ default/files/2016-08/MBR-Deforestation-Trends.pdf

Holzman, B. A. 2008. Tropical forest biomes. Greenwood, London, UK. 
Instituto Nacional de Estadística, Geografía e Informática (INEGI). 2012. Carta hidrogeológica. Istmo de Tehuantepec, Oaxaca. Escala: 1, 250 000, México. INEGI, Mexico City, Mexico.

Karubian, J., J. Fabara, D. Yunes, J. P. Jorgenson, D. Romo, and T. B. Smith. 2005. Temporal and spatial patterns of macaw abundance in the Ecuadorian Amazon. Condor 107:617-626. http://dx.doi.org/10.1650/0010-5422(2005)107[0617:TASPOM]2.0. $\mathrm{CO} ; 2$

Kinnaird, M. F., T. G. O'Brien, F. R. Lambert, and D. Purmiasa. 2003. Density and distribution of the endemic Seram Cockatoo Cacatua moluccensis in relation to land use patterns. Biological Conservation 109:227-235. http://dx.doi.org/10.1016/S0006-3207 (02)00150-7

Krebs, C. J. 1999. Ecological methodology. Second edition. Addison-Welsey Educational Publishers, Menlo Park, California, USA.

Lawton, J. H., D. E. Bignell, B. Bolton, G. F. Bloemers, P. Eggleton, P. M. Hammond, M. Hodda, R. D. Holt, T. B. Larsen, N. A. Mawdsley, N. E. Stork, D. S. Srivastava, and A. D. Watt. 1998. Biodiversity inventories, indicator taxa and effects of habitat modification in tropical forest. Nature 391:72-76. http:// dx.doi.org/doi:10.1038/34166 http://dx.doi.org/10.1038/34166

Lee, A. T. K., D. J. Brightsmith, M. P. Vargas, K. Q. Leon, A. J. Mejia, and S. J. Marsden. 2014. Diet and geophagy across a western Amazonian parrot assemblage. Biotropica 46:322-330. http://dx.doi.org/10.1111/btp.12099

Lee, A. T. K., and S. T. Marsden. 2012. The influence of habitat, season, and detectability on abundance estimates across an Amazonia parrot assemblage. Biotropica 44:537-544. http://dx. doi.org/10.1111/j.1744-7429.2011.00847.x

Legault, A., V. Chartendraul, J. Theuerkauf, S. Rouys, and N. Barré. 2011. Large-scale habitat selection by parrots in New Caledonia. Journal of Ornithology 152:409-419. http://dx.doi. org/10.1007/s10336-010-0602-0

Leighton, M., and D. R. Leighton. 1983. Vertebrate responses to fruiting seasonality within a Bornean rain forest. Pages 181-196 in T. C. Whitmore and A. C. Chadwick, editors. Tropical rainforest: ecology and management. Blackwell Scientific, Oxford, UK.

Loiselle, B. A. 1988. Bird abundance and seasonality in a Costa Rican lowland rainforest canopy. Condor 90:761-772. http://dx. doi.org/10.2307/1368833

MacGregor-Fors, I., and M. E. Payton. 2013. Contrasting diversity values: statistical inferences based on overlapping confidence intervals. PLOS ONE 8:e56794. http://dx.doi. org/10.1371/journal.pone.0056794

Marques, F. F. C., and S. T. Buckland. 2003. Incorporating covariates into standard line transect analyses. Biometrics 59:924-935. http://dx.doi.org/10.1111/j.0006-341X.2003.00107. $\mathrm{x}$

Marques, T. A., L. Thomas, S. G. Fancy, and S. T. Buckland. 2007. Improving estimates of bird density using multiple-covariate distance sampling. Auk 124:1229-1243. http://dx.doi. org/10.1642/0004-8038(2007)124[1229:IEOBDU]2.0.CO;2
Marsden, S. J. 1992. The distribution, abundance and habitat preferences of the Salmon-crested Cockatoo Cacatua moluccensis on Seram, Indonesia. Bird Conservation International 2:7-13. http://dx.doi.org/10.1017/S0959270900000435

Marsden, S. J. 1999. Estimation of parrot and hornbill densities using a point count distance sampling method. Ibis 141:377-390. http://dx.doi.org/10.1111/j.1474-919X.1999.tb04405.x

Marsden, S. J., and J. D. Pilgrim. 2003. Factors influencing the abundance of parrots and hornbills in pristine and disturbed forests on New Britain, PNG. Ibis 145:45-53. http://dx.doi. org/10.1046/j.1474-919X.2003.00107.x

Marsden, S. J., and K. Royle. 2015. Abundance and abundance change in the world's parrots. Ibis 157:219-229. http://dx.doi. org/10.1111/ibi.12236

Marsden, S. J., and C. T. Symes. 2006. Abundance and habitat associations of parrots at a hillforest site in Papua New Guinea. Pacific Conservation Biology 12:15-21. http://dx.doi.org/10.1071/ PC060015

Marsden, S. J., M. Whiffin, L. Sadgrove, and P. Guimarães Jr. 2000. Parrot populations and habitat use in and around two lowland Atlantic forest reserves, Brazil. Biological Conservation 96:209-217. http://dx.doi.org/10.1016/S0006-3207(00)00071-9

Martínez-Pacheco, A. I. 2012. Monitoreo del cambio de uso de suelo en Los Chimalapas 2000-2003. Pages 86-94 in D. Ortega del Valle, T. Carranza-López, and J. Martínez-Pérez, editors. Una mirada desde el corazón de la jícara de oro. Experiencias de conservación en la Selva Zoque de Los Chimalapas. WWF-México, Oaxaca, Mexico.

Monterrubio-Rico, T. C., J. F. Charre-Medellín, C. PachecoFigueroa, S. Arriaga-Weiss, J. D. Valdez-Leal, R. CancinoMurillo, G. Escalona-Segura, C. Bonilla-Ruiz, and Y. RubioRocha. 2016. Distribución potencial histórica y contemporánea de la familia Psittacidae en México. Revista Mexicana de Biodiversidad 87:1103-1117. http://dx.doi.org/10.1016/j.rmb.2016.06.004

Morellato, L. P. C., M. G. Camargo, and E. Gressler. 2013. A review of plant phenology in South and Central America. Pages 91-113 in M. D. Schwarts, editor. Phenology: an interactive environmental science. Second edition. Springer, New York, New York, USA. http://dx.doi.org/10.1007/978-94-007-6925-0_6

Navarro-Sigüenza, A. G., L. C. Márquez, and H. O. Monroy. 2008. Vertebrados terrestres de Los Chimalapas: una prioridad de conservación. CONABIO. Biodiversitas 77:10-15. [online] URL: http://www.biodiversidad.gob.mx/Biodiversitas/Articulos/ biodiv77art3.pdf

Nue, C. W., C. R. Byers, and J. M. Peek. 1974. A technique for analysis of utilization-availability data. Journal of Wildlife Management 38:541-545. http://dx.doi.org/10.2307/3800887

Olah, G., S. H. M. Butchart, A. Symes, I. Medina Guzmán, R. Cunningham, D. J. Brightsmith, and R. Heinsohn. 2016. Ecological and socio-economic factors affecting extinction risk in parrots. Biodiversity and Conservation 25:205-223. http://dx. doi.org/10.1007/s10531-015-1036-Z

Olson, D. M., E. Dinerstein, E. D. Wikramanayake, N. D. Burgess, G. V. N. Powell, E. C. Underwood, J. A. D'Amico, I. Itoua, H. E. Strand, J. C. Morrison, C. J. Loucks, T. F. Allnutt, T. H. Ricketts, 
Y. Kura, J. F. Lamoreux, W. W. Wettengel, P. Hedao, and K. R. Kassem. 2001. Terrestrial ecoregions of the world: a new map of life on Earth. BioScience 51:933-938.

Payton, M. E., M. H. Greenstone, and N. Schenker. 2003. Overlapping confidence intervals or standard error intervals: what do they mean in terms of statistical significance? Journal of Insect Science 3:1-6. http://dx.doi.org/10.1673/031.003.3401

Peh, K. S.-H., J. de Jong, N. S. Sodhi, S. L.-H. Lim, and C. A.M. Yap. 2005. Lowland rainforest avifauna and human disturbance: persistence of primary forest birds in selectively logged forests and mixed-rural habitats of southern Peninsular Malaysia. Biological Conservation 123:489-505. http://dx.doi. org/10.1016/j.biocon.2005.01.010

Pennington, T. D., and J. Sarukhán. 1998. Arboles tropicales de México. Second edition. Fondo de Cultura Económica, Mexico City, Mexico.

Peterson, A. T., and A. G. Navarro-Sigüenza. 2016. Bird conservation and biodiversity research in Mexico: status and priorities. Journal of Field Ornithology 87:121-132. http://dx.doi. org/10.1111/jofo. 12146

Peterson, A. T., A. G. Navarro-Sigüenza, B. E. Hernández-Baños, G. Escalona-Segura, F. Rebón-Gallardo, E. Rodríguez-Ayala, E. M. Figueroa-Esquivel, and L. Cabrera-García. 2003. The Chimalapas region, Oaxaca, Mexico: a high-priority region for bird conservation in Mesoamerica. Bird Conservation International 13:227-253. http://dx.doi.org/10.1017/S0959270903003186

QGIS Development Team. 2015. QGIS geographic information system. Open Source Geospatial Foundation Project. [online] URL: http://www.qgis.org/

R Core Team. 2016. R: A language and environment for statistical computing. R Foundation for Statistical Computing, Vienna, Austria. [online] URL: http://www.R-project.org/

Renton, K. 2002. Seasonal variation in occurrence of macaws along a rainforest river. Journal of Field Ornithology 73:15-19. http://dx.doi.org/10.1648/0273-8570-73.1.15

Ríos-Muñoz, C. A., and A. G. Navarro-Sigüenza. 2009. Efectos del cambio de uso del suelo en la disponibilidad hipotética de hábitat para los psitácidos de México. Ornitologia Neotropical 20:491-509.

Saunders, D. A. 1990. Problems of survival in an extensively cultivated landscape: the case of Carnaby's Cockatoo Calyptorhynchus funereus latirostris. Biological Conservation 54:277-290. http://dx.doi.org/10.1016/0006-3207(90)90057-V

Şekercioğlu, C. H., G. C. Daily, and P. R. Ehrlich. 2004. Ecosystem consequences of bird declines. Proceedings of the National Academy of Sciences USA 101:18042-18047. http://dx.doi. org/10.1073/pnas.0408049101

Skole, D., and C. Tucker. 1993. Tropical deforestation and habitat fragmentation in the Amazon: satellite data from 1978 to 1988. Science 260:1905-1910. http://dx.doi.org/10.1126/science.260.5116.1905

Snyder, N., P. McGowan, J. Gilardi, and A. Grajal. 2000. Parrots. Status survey and conservation action plan 2000-2004. IUCN, Gland, Switzerland and Cambridge, UK.
Symes, C. T., and S. J. Marsden. 2007. Patterns of supra-canopy flight by pigeons and parrots at a hill-forest site in Papua New Guinea. Emu 107:115-125. http://dx.doi.org/10.1071/MU06041

Symonds, M. R. E., and A. Moussalli. 2011. A brief guide to model selection, multimodel inference and model averaging in behavioural ecology using Akaike's information criterion. Behavioral Ecology and Sociobiology 65:13-21. http://dx.doi. org/10.1007/s00265-010-1037-6

Thomas, L., S. T. Buckland, E. A. Rexstad, J. L. Laake, S. Strindberg, S. L. Hedley, J. R. B. Bishop, T. A. Marques, and K. P. Burnham. 2010. Distance software: design and analysis of distance sampling surveys for estimating population size. Journal of Applied Ecology 47:5-14. http://dx.doi.org/10.1111/ j.1365-2664.2009.01737.x

Torquebiau, E. F. 1986. Mosaic patterns in Dipterocarp rain forest in Indonesia, and their implications for practical forestry. Journal of Tropical Ecology 2:301-325. [online] URL: http://www.jstor. org/stable/2559460

Torres Colín, R. 2004. Tipos de vegetación. Pages 105-117 in A. J. García-Mendoza, M. J. Ordoñez, and M. Briones-Salas, editors. Biodiversidad de Oaxaca. Instituto de Biología, UNAM, Fondo Oaxaqueño para la Conservación de la Naturaleza, WWFMéxico, Mexico City, Mexico.

Trejo, I. 2004. Clima. Pages 67-85 in A. J. García-Mendoza, M. J. Ordoñez, and M. Briones-Salas, editors. Biodiversidad de Oaxaca. Instituto de Biología, UNAM, Fondo Oaxaqueño para la Conservación de la Naturaleza, WWF-México, Mexico City, Mexico.

van Horne, B. 1983. Density as a misleading indicator of habitat quality. Journal of Wildlife Management 47:893-901. http://dx. doi.org/10.2307/3808148

Vázquez Torres, M., S. Armenta Montero, J. Campos Jiménez, and C. I. Carvajal Hernández. 2010. Árboles de la región de Los Tuxtlas. Secretaria de Educación-Gobierno del Estado de Veracruz, Xalapa, Veracruz, Mexico.

Vitousek, P. M., H. A. Mooney, J. Lubchenco, and J. M. Melillo. 1997. Human domination of Earth's ecosystems. Science 277:494-499. http://dx.doi.org/10.1126/science.277.5325.494

Wagenmakers, E. J., and S. Farrell. 2004. AIC model selection using Akaike weights. Psychonomic Bulletin and Review 11:192-196. http://dx.doi.org/10.3758/BF03206482

Wenner, T. J., M. A. Russello, and T. F. Wright. 2012. Cryptic species in a Neotropical parrot: genetic variation within the Amazona farinosa species complex and its conservation implications. Conservation Genetics 13:1427-1432. http://dx.doi. org/10.1007/s10592-012-0364-8

Wood, S. N. 2006. Generalized additive models: an introduction with $R$. Chapman and Hall/CRC, Boca Raton, Florida, USA

Wood, S. N. 2011. Fast stable restricted maximum likelihood and marginal likelihood estimation of semiparametric generalized linear models. Journal of the Royal Statistical Society B 73:3-36. http://dx.doi.org/10.1111/j.1467-9868.2010.00749.x 
Wright, S. J., and H. C. Muller-Landau. 2006a. The future of tropical forest species. Biotropica 38:287-301. http://www.jstor. org/stable/30043245 http://dx.doi.org/10.1111/j.1744-7429.2006.00154.

$\mathrm{x}$

Wright, S. J., and H. C. Muller-Landau. 2006b. The uncertain future of tropical forest species. Biotropica 38:443-445. http://dx. doi.org/10.1111/j.1744-7429.2006.00177.x

Zar, J. H. 1999. Biostatistical analysis. Fourth edition. Prentice Hall, Upper Saddle River, New Jersey, USA. 
Appendix 1. Supplementary tables of model parameters used in Distance and GAM analyses.

Table A1.1. Tree species occurring in our study site that are reported in the diet or used as nestsites by mealy parrots (Amazona guatemalae and A. farinosa)

\begin{tabular}{|c|c|c|c|c|}
\hline Family/Plant species & $\begin{array}{l}\text { Data } \\
\text { sourced }\end{array}$ & Region & Country & Reference \\
\hline \multicolumn{5}{|l|}{ Apocynaceae } \\
\hline Aspidosperma megalocarpo & Diet & $\begin{array}{l}\text { Central and } \\
\text { South America }\end{array}$ & $\begin{array}{l}\text { Guatemala, } \\
\text { Peru }\end{array}$ & $\begin{array}{l}\text { Bjork } 2004, \text { Lee et } \\
\text { al. } 2014\end{array}$ \\
\hline \multicolumn{5}{|l|}{ Anacardiaceae } \\
\hline Astronium graveolens & Diet & South America & Peru & Lee et al. 2014 \\
\hline Spondias mombin & Nest-tree & Central America & Guatemala & Bjork 2004 \\
\hline \multicolumn{5}{|l|}{ Bombacaceae } \\
\hline Ochroma pyramidale & Diet & South America & Peru & Lee et al. 2014 \\
\hline \multicolumn{5}{|l|}{ Clusiaceae } \\
\hline Calophyllum brasiliense & $\begin{array}{l}\text { Nest-tree } \\
\text { and diet }\end{array}$ & Central America & Guatemala & Bjork 2004 \\
\hline \multicolumn{5}{|l|}{ Combretaceae } \\
\hline Terminalia amazonica & $\begin{array}{l}\text { Nest-tree } \\
\text { and diet }\end{array}$ & Central America & Guatemala & Bjork 2004 \\
\hline \multicolumn{5}{|l|}{ Fabaceae } \\
\hline Dialium guienense & Diet & South America & Peru & Lee et al. 2014 \\
\hline Enterolobium cyclocarpum & Nest-tree & Central America & Guatemala & Bjork 2004 \\
\hline Vatairea lundelii & $\begin{array}{l}\text { Nest-tree } \\
\text { and diet }\end{array}$ & Central America & Guatemala & Bjork 2004 \\
\hline \multicolumn{5}{|l|}{ Elaeocarpaceae } \\
\hline Sloanea sp. & Diet & South America & Peru & Lee et al. 2014 \\
\hline \multicolumn{5}{|l|}{ Moraceae } \\
\hline Brosimun alicastrum & $\begin{array}{l}\text { Nest-tree } \\
\text { and diet }\end{array}$ & $\begin{array}{l}\text { Central and } \\
\text { South America }\end{array}$ & $\begin{array}{l}\text { Guatemala, } \\
\text { Peru }\end{array}$ & $\begin{array}{l}\text { Bjork 2004, Lee et } \\
\text { al. } 2014\end{array}$ \\
\hline Ficus sp. & $\begin{array}{l}\text { Nest-tree } \\
\text { and diet }\end{array}$ & $\begin{array}{l}\text { Central and } \\
\text { South America }\end{array}$ & $\begin{array}{l}\text { Guatemala, } \\
\text { Peru }\end{array}$ & $\begin{array}{l}\text { Bjork 2004, Lee et } \\
\text { al. } 2014\end{array}$ \\
\hline \multicolumn{5}{|l|}{ Sapotaceae } \\
\hline Manilkara zapota & Nest-tree & Central America & Guatemala & Bjork 2004 \\
\hline Pouteria sapota & Nest-tree & Central America & Guatemala & Bjork 2004 \\
\hline
\end{tabular}


Table A1.2. Multiple-covariates distance sampling models with forest structure covariates for density of Northern Mealy Amazons during the breeding season (March 2014) in tropical moist forest of Los Chimalapas, Mexico. Models are ordered by the lowest Akaike's Information Criterion (AIC), with delta Akaike differences ( $\triangle \mathrm{AIC}$ ), and Akaike weights (AICwi) between models. $\mathrm{K}=$ number of parameters; $\% \mathrm{CV}=$ Coefficient of Variation for each density model.

\begin{tabular}{|c|c|c|c|c|c|c|}
\hline $\begin{array}{l}\text { Model and } \\
\text { adjustment terms }\end{array}$ & Covariates & $\% \mathrm{CV}$ & $\overline{\mathrm{K}}$ & $\overline{\mathrm{AIC}}$ & $\Delta \mathrm{AIC}$ & $\overline{\mathrm{AICw}}$ \\
\hline $\begin{array}{l}\text { Half-normal } \\
\text { cosine }\end{array}$ & $\begin{array}{c}\text { Tree density }+ \text { mean } \\
\text { height }\end{array}$ & 25.6 & 5 & 1220.0 & 0.0 & 0.26 \\
\hline $\begin{array}{l}\text { Half-normal } \\
\text { simple polynomial }\end{array}$ & $\begin{array}{c}\text { Tree density }+ \text { mean } \\
\text { height }\end{array}$ & 80.8 & 5 & 1221.3 & 1.3 & 0.14 \\
\hline $\begin{array}{l}\text { Half-normal } \\
\text { cosine }\end{array}$ & $\begin{array}{l}\text { Tree density }+ \text { mean } \\
\text { height }+ \text { mean dbh }\end{array}$ & 25.9 & 6 & 1221.7 & 1.7 & 0.11 \\
\hline $\begin{array}{l}\text { Half-normal } \\
\text { cosine }\end{array}$ & mean height & 25.7 & 4 & 1222.5 & 2.5 & 0.07 \\
\hline $\begin{array}{l}\text { Half-normal } \\
\text { cosine }\end{array}$ & $\begin{array}{l}\text { mean } \mathrm{dbh}+\text { mean } \\
\text { height }\end{array}$ & 25.9 & 5 & 1222.6 & 2.6 & 0.07 \\
\hline $\begin{array}{l}\text { Half-normal } \\
\text { simple polynomial }\end{array}$ & mean height & 63.1 & 4 & 1223.3 & 3.3 & 0.05 \\
\hline $\begin{array}{l}\text { Hazard simple } \\
\text { polynomial }\end{array}$ & $\begin{array}{c}\text { mean } \mathrm{dbh}+\text { mean } \\
\text { height }\end{array}$ & 25.8 & 4 & 1223.3 & 3.3 & 0.05 \\
\hline Hazard cosine & $\begin{array}{c}\text { mean } \mathrm{dbh}+\text { mean } \\
\text { height }\end{array}$ & 25.8 & 4 & 1223.3 & 3.3 & 0.05 \\
\hline $\begin{array}{l}\text { Half-normal } \\
\text { simple polynomial }\end{array}$ & $\begin{array}{c}\text { mean } \mathrm{dbh}+\text { mean } \\
\text { height }\end{array}$ & 65.6 & 5 & 1223.8 & 3.8 & 0.04 \\
\hline $\begin{array}{l}\text { Hazard simple } \\
\text { polynomial }\end{array}$ & $\begin{array}{l}\text { Tree density }+ \text { mean } \\
\text { dbh }\end{array}$ & 31.2 & 5 & 1223.9 & 3.9 & 0.04 \\
\hline $\begin{array}{l}\text { Half-normal } \\
\text { cosine }\end{array}$ & $\begin{array}{c}\text { Tree density }+ \text { mean } \\
\text { dbh }\end{array}$ & 25.7 & 5 & 1224.5 & 4.5 & 0.03 \\
\hline $\begin{array}{l}\text { Half-normal } \\
\text { cosine }\end{array}$ & Tree density & 25.7 & 4 & 1224.6 & 4.6 & 0.03 \\
\hline Hazard cosine & $\begin{array}{l}\text { Tree density }+ \text { mean } \\
\text { dbh }\end{array}$ & 25.4 & 4 & 1225.9 & 5.9 & 0.01 \\
\hline $\begin{array}{l}\text { Hazard simple } \\
\text { polynomial }\end{array}$ & mean height & 90.3 & 5 & 1226.1 & 6.1 & 0.01 \\
\hline $\begin{array}{l}\text { Half-normal } \\
\text { simple polynomial }\end{array}$ & Tree density & 79.9 & 4 & 1226.3 & 6.3 & 0.01 \\
\hline $\begin{array}{l}\text { Hazard simple } \\
\text { polynomial }\end{array}$ & $\begin{array}{c}\text { Tree density }+ \text { mean } \\
\text { height }\end{array}$ & 25.7 & 5 & 1226.6 & 6.6 & 0.01 \\
\hline $\begin{array}{l}\text { Half-normal } \\
\text { simple polynomial }\end{array}$ & $\begin{array}{l}\text { Tree density }+ \text { mean } \\
\text { dbh }\end{array}$ & 80.3 & 5 & 1226.7 & 6.7 & 0.01 \\
\hline Hazard cosine & $\begin{array}{c}\text { Tree density }+ \text { mean } \\
\text { height }\end{array}$ & 25.4 & 4 & 1228.1 & 8.1 & 0.00 \\
\hline $\begin{array}{l}\text { Hazard simple } \\
\text { polynomial }\end{array}$ & Tree density & 25.8 & 4 & 1228.6 & 8.6 & 0.00 \\
\hline
\end{tabular}




\begin{tabular}{lcccccc}
\hline $\begin{array}{l}\text { Hazard simple } \\
\text { polynomial } \\
\text { Hazard cosine }\end{array}$ & $\begin{array}{c}\text { Tree density }+ \text { mean } \\
\text { height }+ \text { mean dbh } \\
\text { Tree density }+ \text { mean } \\
\text { height }+ \text { mean dbh } \\
\text { Tree density }\end{array}$ & 60.8 & 5 & 1229.3 & 9.3 & 0.00 \\
$\begin{array}{l}\text { Hazard cosine } \\
\text { Hazard simple } \\
\text { polynomial }\end{array}$ & mean dbh & 25.9 & 4 & 1230.6 & 10.6 & 0.00 \\
$\begin{array}{l}\text { Hazard cosine } \\
\text { Hazard cosine }\end{array}$ & mean dbh & 25.4 & 3 & 1231.4 & 11.4 & 0.00 \\
$\begin{array}{l}\text { Half-normal } \\
\text { cosine }\end{array}$ & mean height & 25.3 & 3 & 1231.4 & 11.4 & 0.00 \\
$\begin{array}{l}\text { Half-normal } \\
\text { simple polynomial }\end{array}$ & mean dbh & 57.8 & 4 & 1236.0 & 16.0 & 0.000 \\
\hline
\end{tabular}


Table A1.3. Results of GAMs incorporating three principal components (PC) to predict: a) abundance, and b) presence of Northern Mealy Amazons during the breeding season (March 2014) in a modified landscape of tropical moist forest, Los Chimalapas, Mexico. Models are ordered by the lowest Akaike's Information Criterion (AIC), with delta Akaike differences $(\triangle \mathrm{AIC})$, and Akaike weights (AICwi) between models. $\mathrm{K}=$ total number of parameters.

a) Number of Northern Mealy Amazons at point count

\begin{tabular}{cccccc}
\hline \hline Models & Deviance explained (\%) & $\mathrm{K}$ & AIC & $\Delta$ AIC & AICwi \\
\hline PC1 + PC2 + PC3 & 73.8 & 4 & 508.3 & 0.0 & 1.0 \\
PC1 + PC2 & 57.3 & 3 & 543.9 & 35.6 & 0.0 \\
PC2 + PC3 & 50.4 & 3 & 576.7 & 68.4 & 0.0 \\
PC2 & 37.6 & 2 & 596.8 & 88.5 & 0.0 \\
PC1+ PC3 & 37 & 3 & 636.1 & 127.8 & 0.0 \\
PC1 & 26.1 & 2 & 674.9 & 166.6 & 0.0 \\
PC3 & 11.6 & 2 & 718.9 & 210.6 & 0.0 \\
\hline
\end{tabular}

b) Presence of Northern Mealy Amazons within $50 \mathrm{~m}$ of point count

\begin{tabular}{cccccc}
\hline \hline Models & Deviance explained (\%) & $\mathrm{K}$ & $\mathrm{AIC}$ & $\Delta$ AIC & AICwi \\
\hline PC1 + PC2 + PC3 & 34.9 & 4 & 94.1 & 0.0 & 0.53 \\
PC1 + PC2 & 29.5 & 3 & 94.4 & 0.3 & 0.45 \\
PC2 + PC3 & 28.1 & 3 & 101.6 & 7.5 & 0.01 \\
PC2 & 20.7 & 2 & 103.4 & 9.3 & 0.01 \\
PC1 + PC3 & 12.9 & 3 & 106.6 & 12.5 & 0.00 \\
PC1 & 7.5 & 2 & 108.1 & 14 & 0.00 \\
PC3 & 3.8 & 2 & 112.1 & 18 & 0.00 \\
\hline
\end{tabular}

